Jurnal Progres Ekonomi Pembangunan (JPEP)

Volume 4, Nomor 2 , Tahun 2019

Page: $1-19$

http://ojs.uho.ac.id/index.php/JPEP

e-ISSN: 2052-5171

\title{
ANALISIS KINERJA KEUANGAN DAN KEMAMPUAN KEUANGAN PEMERINTAH DAERAH DALAM PELAKSANAAN OTONOMI DAERAH DI PROVINSI SULAWESI TENGGARA
}

\author{
Israwati Mustarim \\ Program Pascasarjana Universitas Halu Oleo, Kendari \\ Email: israwati.mustarim@gmail.com \\ Rosnawintang \\ nanarosnawintang@gmail.com
}

Fakultas Ekonomi dan Bisnis Universitas Halu Oleo Kendari

Mulyati Akib

mulyatiakib@yahoo.co.id

Fakultas Ekonomi dan Bisnis Universitas Halu Oleo Kendari

\begin{abstract}
This study aims to analyze financial performance and financial capacity in implementing regional autonomy. The object of this research is financial performance and financial capacity in the implementation of regional autonomy in 2011 to 2017. The data collection techniques of this study describe, analyze and interpret the financial performance and financial capabilities of the Regency / City government of Southeast Sulawesi Province which are measured by calculating financial ratios based on reports realization of APBD for fiscal year 2011-2017 and presented in writing in a systematic manner. The results of this study found that financial performance is still not financially independent and is in an innovative relationship pattern, where external parties are still very much needed in government administration, the effectiveness of PAD is very good and indirect expenditure activities in parent regions are allocated more than 50 percent, while for autonomous regions direct expenditure is allocated more than 50 percent, financial capability measured by the degree of fiscal autonomy is in the very low category but the financial ability index is very good.
\end{abstract}

Keywords: Regional Autonomy, Financial Ability, Financial Performance

\section{PENDAHULUAN}

Otonomi Daerah mulai diberlakukan sejak dikeluarkannya Undang-Undang No. 1 tahun 1957 dan mengalami berbagai perubahan menjadi Undang-Undang (UU) No. 9 Tahun 2015 tentang Pemerintah Daerah (Pemda). Otonomi daerah adalah kewenangan daerah otonom untuk mengatur dan mengurus kepentingan masyarakat setempat menurut prakarsa sendiri berdasarkan aspirasi masyarakat sesuai peraturan perundang-undangan. Pemerintah daerah berwenang untuk mengatur dan mengurus sendiri urusan pemerintahan menurut asas otonomi dan tugas pembantuan. Pemberian otonomi luas kepada daerah diarahkan untuk mempercepat terwujudnya 
Jurnal Progres Ekonomi Pembangunan (JPEP)

Volume 4, Nomor 2 , Tahun 2019

Page: $1-19$

http://ojs.uho.ac.id/index.php/JPEP

e-ISSN: 2052-5171

kesejahteraan masyarakat melalui peningkatan pelayanan, pemberdayaan dan peran serta masyarakat.

Undang Undang No. 22 Tahun 1999 tentang Otonomi Daerah mendorong kecenderungan baru dalam pemekaran wilayah administratif pada struktur pemerintahan di Indonesia (Bappenas, 2008). Data peningkatan wilayah administratif di Indonesia sejak diberlakukannya UU No. 22 Tahun 1999 sampai dengan Tahun 2017 dapat dilihat pada tabel berikut.

Tabel 1.1

Perkembangan Wilayah Administratif di Indonesia

\begin{tabular}{|c|c|c|}
\hline Keterangan & Tahun 1999-2013 & Tahun 2017 \\
\hline Kabupaten & 175 Kabupaten & 416 Kabupaten \\
\hline Kota & 34 Kota & 98 Kota \\
\hline Provinsi & 30 Provinsi & 34 Provinsi \\
\hline
\end{tabular}

Sumber : (Kementerian Dalam Negeri, 2017)

Tabel tersebut menggambarkan daerah otonom baru (DOB) pada awal tahun 1999 sampai dengan tahun 2017 yang telah mengalami peningkatan yang pesat. Wilayah Indonesia pada tahun 1999 sampai 2013 terdiri dari 175 Kabupaten, 34 kota dan 30 Provinsi meningkat menjadi 416 Kabupaten, 98 Kota dan 34 Provinsi. Provinsi Sulawesi Tenggara adalah salah satu provinsi yang juga melakukan pemekaran wilayah (DOB). Selama kurun waktu 2004 sampai pada 2016 Provinsi Sulawesi Tenggara terdiri dari 4 (empat) kabupaten kemudian berkembang menjadi 17 (Tujuh belas) Kabupaten dan Kota.

Lonjakan drastis jumlah daerah otonom baru ditambah dengan masih banyaknya usulan pembentukan daerah otonom baru yang masuk ke pemerintah dan DPR memunculkan sejumlah pertanyaan mendasar mengenai urgensi dan manfaat dari pemekaran daerah tersebut.

Evaluasi Penyelenggaraan Pemerintah Daerah Provinsi Sulawesi Tenggara yang dilakukan oleh Dirjen Otonomi Daerah Kementerian Dalam Negeri mendapatkan hasil yang berbeda dari penelitian Sadjiarto (2000) dan Khairuddin (2013) tersebut, dimana dalam perkembangannya, Opini yang diberikan oleh BPK tidak serta merta mencerminkan keberhasilan penyelenggaraan pemerintahan dan pengelolaan keuangan yang baik dengan perolehan skor EKPPD (Tinggi, Sedang, Rendah).

Pada tahun 2011, Provinsi Sulawesi Tenggara mendapatkan Opini WDP tetapi skor EKPPD berada pada tingkat Sedang (skor 1,7544 dan berada di peringkat 31), Sedangkan Kab. Bombana dengan Opini TMP yang diberikan BPK mendapatkan hasil yang Tinggi (skor 2,3186 dan berada pada peringkat 302) pada EKPPD. Hasil Penialaian Evaluasi pada 18 DOB dibawah lima tahun oleh Ditjen Otda Kemendagri, menemukan bahwa Kab. Buton Selatan dianggap masih belum memenuhi indikator baik dalam hal insfrastruktur maudpun administratif, apabila 
Jurnal Progres Ekonomi Pembangunan (JPEP)

Volume 4, Nomor 2 , Tahun 2019

Page: $1-19$

http://ojs.uho.ac.id/index.php/JPEP

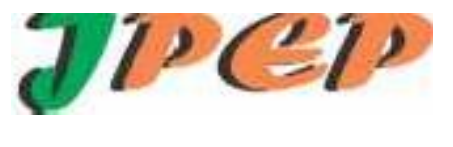

e-ISSN: 2052-5171

kinerja pemerintahan Kab. Buton Selatan tidak memenuhi indikator penilaian maka akan dikembalikan ke kabupaten Induk (http://kendaripos.co.id/2018/08/03/dapat-penilaian-burukdari-kemendagri-busel bakal-dikembalikan-ke-buton/)

Ciri utama suatu daerah yang mampu melaksanakan otonomi, yaitu (1) kemampuan keuangan daerah, artinya daerah harus memiliki kewenangan dan kemampuan untuk menggali sumber-sumber keuangan, mengelola dan menggunakan keuangan sendiri yang cukup memadai untuk membiayai penyelenggaraan pemerintahannya, dan (2) ketergantungan kepada bantuan pusat harus seminimalmungkin, agar pendapatan asli daerah (PAD) dapat menjadi bagian sumber keuangan terbesar sehingga peranan pemerintah daerah menjadi lebih besar (Halim,2001). Pemeriksaan administratif terhadap laporan Keungan Pemerintah Daerah dan Evaluasi Kinerja Penyelenggaraan Pemerintah Daerah belum dapat menggambarkan Kinerja Pemerintah secara keseluruhan.

Kinerja pemerintah kabupaten/kota menjadi poin penting serta topik yang menarik untuk diteliti. Hal ini dikarenakan, dengan meneliti kinerja pemerintah daerah dapat diketahui hasil program dan kegiatan yang dilaksanakan oleh pemerintah, apakah pemerintah sudah baik menjalankan tugas dan fungsinya sesuai yang diamanatkan oleh rakyatnya untuk mencapai kesejahteraan (Mirza, 2012). Oleh karena itu, diperlukan pengukuran kinerja keuangan dan kemampuan keuangan guna mlihat keberhasilan dari pemerintah daerah mewujudkan keberhasilan daerah dalam pelaksanaan otonomi daerah mengedepankan nilai value for money dan mampu dalam mengelola keuangan daerah sehinggat tidak bergantung pada dana pusat, sehingga secara optimal dapat mengelola kemampuan keuangan hal keuangan untuk dapat secara mandiri dalam pembiayaan urusan pemerintahan.

Berdasarkan uraian di atas, maka penulis tertarik untuk melakukan penelitian dengan judul "Analisis Kinerja Keuangan dan Kemampuan Keuangan Pemerintah Daerah Dalam Pelaksanaan Otonomi Daerah di Provinsi Sulawesi Tenggara”.

\section{TINJAUAN PUSTAKA}

Menurut pasal 1 UU No. 32 Tahun 2004, otonomi daerah adalah hak, wewenang, dan kewajiban daerah otonom untuk mengatur dan mengurus sendiri urusan pemerintahan dan kepentingan masyarakat setempat sesuai dengan peraturan perundang-undangan. Daerah Otonom adalah kesatuan masyarakat hukum yang mempunyai batas-batas wilayah yang berwenang mengatur dan mengurus urusan pemerintahan dan kepentingan masyarakat setempat menurut prakarsa sendiri berdasarkan aspirasi masyarakat dalam sistem Negara Kesatuan Republik Indonesia.

Otonomi Daerah adalah hak dan wewenang untuk mengatur dan mengurus rumah tangganya sendiri. Urusan rumah tangga sendiri ialah urusan yang lahir atas adanya prakarsa daerah dan dibiayai dengan pendapatan daerah yang bersangkutan (Kaho,1998). Otonomi daerah 
Jurnal Progres Ekonomi Pembangunan (JPEP)

Volume 4, Nomor 2 , Tahun 2019

Page: $1-19$

http://ojs.uho.ac.id/index.php/JPEP

e-ISSN: 2052-5171

dapat dikatakan berhasil apabila daerah mampu mengatur dan mengurus rumah tangganya sendiri, beberapa ukuran keberhasilan pelaksanaan otonomi daerah dapat dilihat sebagai berikut:

1. Kemampuan struktural organisasi Struktur organisasi pemerintah daerah harus mampu menampung segala aktivitas dan tugas-tugas yang menjadi beban dan tanggung jawabnya, jumlah dan ragam unit cukup, mencerminkan kebutuhan, pembagian tugas, wewenang dan tanggung jawab yang cukup jelas.

2. Kemampuan aparatur pemerintah daerah Aparat pemerintah daerah harus mampu menjalankan tugasnya dalam mengatur dan mengurus rumah tangga daerah. Keahlian, moral, disiplin dan kejujuran saling menunjang tercapainya tujuan yang diinginkan.

3. Kemampuan mendorong partisipasi masyarakat Pemerintah daerah harus mampu mendorong masyarakat agar memiliki kemauan untuk berperan serta dalam kegiatan pembangunan.

4. Kemampuan keuangan daerah Pemerintah daerah harus mampu membiayai kegiatan pemerintahan, pembangunan dan kemasyarakatan secara keseluruhan sebagai wujud pelaksanaan, pengaturan dan pengurusan rumah tangganya sendiri. Sumber-sumber dana antara lain berasal dari PAD atau sebagian dari subsidi pemerintah pusat (Syamsi, 1986).

Kinerja (Performance) diartikan sebagai aktivitas terukur dari suatu entitas selama periode tertentu sebagai bagian dari ukuran keberhasilan pekerjaan (Kamus Akuntansi Manajemen Kontemporer, 1994). Selanjutnya measurement atau pengukuran kinerja diartikan sebagai suatu indikator keuangan dan non keuangan dari suatu pekerjaan yang dilaksanakan atau hasil yang dicapai dari suatu aktivitas, suatu proses atau suatu unit organisasi.

Pengukuran kinerja merupakan wujud akuntabilitas, dimana penilaian yang lebih tinggi menjadi tuntunan yang harus dipenuhi, data pengukuran kinerja dapat menjadi peningkatan program selanjutnya. Kinerja (performance) diartikan sebagai hasil seorang pekerja, sebuah proses manajemen atau suatu organisasi secara keseluruhan, dimana hasil kerja tersebut harus dapat diukur dengan dibandingkan dengan standar yang telah ditentukan (Sedarmayanti,2003)

Sistem pengukuran kinerja sendiri dapat dijadikan sebagai alat pengendalian organisasi. Pemerintah Daerah mempunyai kinerja yang baik apabila Pemerintah Daerah mampu untuk melaksanakan tugas-tugas dalam rangka mencapai tujuan yang telah ditetapkan pada standar yang tinggi dengan biaya yang rendah. Kinerja yang baik bagi Pemerintah Daerah dicapai ketika administrasi dan penyediaan jasa oleh Pemerintah Daerah dilakukan pada tingkat yang ekonomis, efektif dan efisien.

Pengukuran kinerja keuangan Pemerintah Daerah dilakukan untuk memenuhi 3 tujuan yaitu (Mardiasmo,2002) :

1. Memperbaiki kinerja pemerintah

2. Membantu mengalokasikan sumber daya dan pembuatan keputusan

3. Mewujudkan pertanggung jawaban publik dan memperbaiki komunikasi kelembagaan. Analisis kinerja keuangan dapat diketahui dengan menggunakan rasio keuangan (Halim,2007). Penggunaan rasio keuangan sendiri harus di sesuaikan dengan data APBD. 
Jurnal Progres Ekonomi Pembangunan (JPEP)

Volume 4, Nomor 2 , Tahun 2019

Page: $1-19$

http://ojs.uho.ac.id/index.php/JPEP

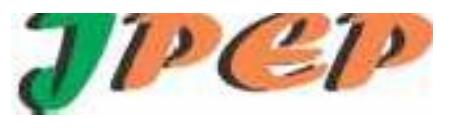

e-ISSN: 2052-5171

Pelaksanaan otonomi daerah tidaklah mudah karena menyangkut masalah kemampuan daerah itu sendiri untuk membiayai urusan pemerintahan beserta pelaksanaan pembangunan dalam upaya meningkatkan kesejahteraan masyarakat. Daerah yang mampu menghasilkan pendapatan daerah baik melalui melalui pendapatan asli daerah maupun dana bagi hasil, hal itu tentunya tidak menjadikan suatu permasalahan. Banyak daerah yang masih harus mengandalkan pemerintah pusat untuk menunjang pelaksanaan pembangunan dan menjalankan kegiatan pemerintahannya.

Peraturan Pemerintah No. 105 tahun 2000, menyebutkan bahwa keuangan daerah adalah semua hak dan kewajiban daerah dalam rangka penyelenggaraan pemerintah daerah yang dapat dinilai dengan uang temasuk didalamnya segala bentuk kekayaan lain yang berhubungan dengan hak dan kewajiban daerah tersebut dalam kerangka APBD. Pasal 4 peraturan pemerintah nomor 105 tahun 2000 tentang pengelolaan keuangan daerah menegaskan bahwa pengelolaan keuangan daerah harus dilakukan secara tertib, taat pada pertauran perundang-undangan yang berlaku, efisien, efektif, transparan, dan bertanggung jawab dengan memperhatikan asas keadilan dan kepatuhan.

Kemampuan daerah dalam mengelola keuangan dituangkan dalam APBD yang langsung maupun tidak langsung mencerminkan kemampuan pemerintah dalam membiayai pelaksanaan tugas - tugas pemerintahan, pembangunan dan pelayan sosial masyarakat.

Hakekat otonomi daerah yaitu berkaitan dengan pelimpahan wewenang pengambilan keputusan kebijakan, pengelolaan dana publik dan pengaturan kegiatan dalam penyelenggaraan pemerintah dan pelayanan masyarakat, maka peranan data keuangan daerah sangat dibutuhkan untuk mengidentifikasi sumber $\neg$ sumber pembiayaan daerah serta jenis dan besar balanja yang harus dikeluarkan agar perencanaan keuangan dapat dilaksanakan secara efektif dan efisien (Yulianti, 2001).

Kemampuan keuangan daerah pada dasarnya adalah kemampuan dari pemerintah daerah dalam meningkatkan pendapatan asli daerahnya sendiri. Menurut (Munir dkk,2004), ciri utama yang menunjukkan suatu daerah mampu berotonomi terletak pada kemampuan keuangan daerah, artinya daerah otonom harus memiliki kewenangan dan kemampuan untuk menggali sumbersumber keuangan sendiri, mengelola dan menggunakan keuangan sendiri yang cukup memadai untuk membiayai penyelenggaraan pemerintahan daerahnya. Kemampuan keuangan daerah pada dasarnya adalah kemampuan dari pemerintah daerah dalam meningkatkan pendapatan asli daerahnya sendiri.

Analisis kemampuan keuangan merupakan kriteria penting untuk mengetahui secara nyata kemampuan daerah dalam mengatur dan mengurus rumah tangga pemerintah daerah. Faktor keuangan merupakan faktor yang penting dalam mengatur tingkat kemampuan daerah dalam melaksanakan otonomi daerah.

Kemampuan keuangan daerah pada dasarnya adalah kemampuan dari pemerintah daerah dalam meningkatkan pendapatan asli daerahnya sendiri. Ciri utama yang menunjukkan suatu daerah mampu berotonomi terletak pada kemampuan keuangan daerah, artinya daerah otonom 
Jurnal Progres Ekonomi Pembangunan (JPEP)

Volume 4, Nomor 2 , Tahun 2019

Page: $1-19$

http://ojs.uho.ac.id/index.php/JPEP

e-ISSN: 2052-5171

harus memiliki kewenangan dan kemampuan untuk menggali sumbersumber keuangan sendiri, mengelola dan menggunakan keuangan sendiri yang cukup memadai untuk membiayai penyelenggaraan pemerintahan daerahnya (Munir dkk,2004).

\section{METODE PENELITIAN}

Jenis penelitian yang dipakai dalam penelitian ini adalah penelitian deskriptif dengan pendekatan kuantitatif. Penelitian deskriptif adalah suatu metode penelitian yang tujuannya adalah untuk membuat deskripsi, gambaran atau lukisan secara sistematis, faktual dan akurat mengenai fakta-fakta, sifat-sifat serta hubungan antara fenomena yang diselidiki. Penelitian ini berupaya untuk mendeskripsikan, menganalis dan menginterpretasikan kinerja keuangan serta kemampuan keuangan pemerintah daerah Kabupaten/Kota di Sulawesi Tenggara yang diukur

\begin{tabular}{|c|c|l|}
\hline $\begin{array}{c}\text { Kemammpuan } \\
\text { Keuangan }\end{array}$ & $\begin{array}{c}\text { Kemandirian } \\
(\%)\end{array}$ & $\begin{array}{l}\text { Pola } \\
\text { Hubungan }\end{array}$ \\
\hline Rendah Sekali & $0 \%-25 \%$ & Instrukjif \\
\hline Rendah & $25 \%-50 \%$ & Konsultatif \\
\hline Sedang & $50 \%-75 \%$ & Partisipatif \\
\hline Tinggi & $75 \%-100 \%$ & Delegatif \\
\hline
\end{tabular}
melalui perhitungan rasio keuangan, disajikan dalam bentuk data time series berdasarkan laporan realisasi APBD tahun anggaran 2011-2017 dan disajikan dalam bentuk tulisan secara sistematis.

Jenis data yang digunakan dalam penelitian ini adalah data sekunder yang bersumber dari buku-buku, literatur, internet, catatan-catatan, serta sumber lain yang berhubungan dengan masalah penelitian. Menurut Dajan (1991) yang dimaksud dengan data sekunder yaitu data yang diterbitkan atau digunakan oleh organisasi yang bukan pengelolanya.

Data yang akan disajikan dalam penelitian ini antara lain :

1. Data APBD Provinsi Kabupaten/Kota pada Provinsi Sulawesi Tenggara tahun 20112017.

2. Data Realisasi APBD Provinsi Kabupaten/Kota pada Provinsi Sulawesi Tenggara tahun 2011-2017. 
Jurnal Progres Ekonomi Pembangunan (JPEP)

Volume 4, Nomor 2 , Tahun 2019

Page: $1-19$

http://ojs.uho.ac.id/index.php/JPEP

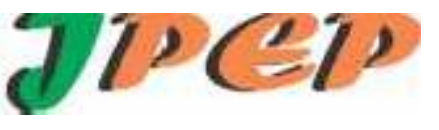

e-ISSN: 2052-5171

3. Data Statistik Keuangan Kabupaten/Kota pada Provinsi Sulawesi Tenggara tahun 20112017.

Penelitian ini berupaya untuk mendeskripsikan, menganalis dan menginterpretasikan kinerja keuangan serta kemampuan keuangan pemerintah daerah Kabupaten/Kota Provinsi Sulawesi Tenggara yang diukur melalui perhitungan rasio keuangan berdasarkan laporan realisasi APBD tahun anggaran 2011-2017 dan disajikan dalam bentuk tulisan secara sistematis.

Analisis ini akan menggambarkan hal-hal yang berkaitan untuk mengetahui kemampuan keuangan serta kinerja keuangan daerah Kabupaten/Kota Provinsi Sulawesi Tenggara kemudian diinterpretasikan dengan menggunakan analisis rasio keuangan. Analisis rasio keuangan pada APBD dilakukan dengan membandingkan hasil yang dicapai dari satu periode dibandingkan dengan periode sebelumnya sehingga dapat diketahui bagaimana kecenderungan yang terjadi. Selain itu dapat pula dilakukan dengan cara membandingkan dengan rasio keuangan daerah lain yang terdekat ataupun yang potensi daerahnya relatif sama untuk dilihat bagaimana posisi rasio keuangan pemerintah tersebut terhadap pemerintah daerah lainnya.

\section{Kinerja Keuangan Daerah}

1. Rasio Kemandirian Keuangan Daerah (RKKD) ditunjukkan oleh besar kecilnya Pendapatan Asli Daerah (PAD) dibandingkan dengan total bantuan dan pinjaman yang diterima daerah. Rumus RKKD yaitu:

$$
\begin{gathered}
R K K D=\frac{\text { Total Penerimaan PAD }}{\text { Total Bantuan Daerah dan Pinjaman }} \times 100 \% \\
\text { Tabel } 4.1 \\
\text { Pola Hubungan dan Tingkat Kemandirian Daerah }
\end{gathered}
$$

Sumber : Halim (2007)

\section{Pola Hubungan Dan Tingkat Kemampuan Daerah}

a. Pola Hubungan Instruktif, peran pemerintah pusat lebih dominan daripada kemandirian Pemerintah Daerah (daerah yang tidak mampu melaksanakan otonomi daerah)

b. Pola Hubungan Konsultatif, dimana campur tangan pemerintah pusat sudah mulai berkurang, karena daerah dianggap sedikit lebih mampu, melaksanakan otonomi.

c. Pola Hubungan Partisipatif, peranan pemerintah pusat semakin berkurang, mengingat daerah bersangkutan tingkat kemandiriannya mendekati mampu melaksanakan urusan otonomi.

d. Pola Hubungan Delegatif, campur tangan pemerintah pusat sudah tidak ada karena daerah telah benar-benar mampu dan mandiri dalam melaksanakan urusan otonomi daerah. 
Jurnal Progres Ekonomi Pembangunan (JPEP)

Volume 4, Nomor 2 , Tahun 2019

Page: $1-19$

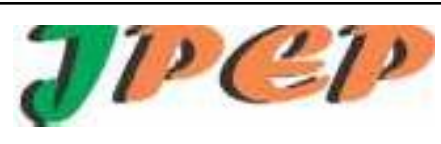

http://ojs.uho.ac.id/index.php/JPEP

e-ISSN: 2052-5171

2. Rasio Efektivitas menggambarkan kemampuan Pemerintah Daerah dalam merealisasikan pendapatan yang direncanakan, kemudian dibandingkan dengan target yang ditetapkan berdasarkan potensi riil daerah (Halim,2012). Semakin tinggi Rasio Efektivitas menggambarkan kemampuan daerah yang semakin baik.

$$
\text { REKD }=\frac{\text { Realisasi Penerimaan } P A D}{\text { Target Penerimaan } P A D} \times 100 \%
$$

Tabel 4.2

Kriteria Analisis Efektivitas Pendapatan Asli Daerah

\begin{tabular}{|c|c|}
\hline Persentase Efektivitas & Kriteria Efektifitas \\
\hline$>100 \%$ & Sangat Efektif \\
\hline $90 \%-100 \%$ & Efektif \\
\hline $80 \%-90 \%$ & Cukup Efektif \\
\hline $60 \%-80 \%$ & Kurang Efektif \\
\hline$<60 \%$ & Tidak Efektif \\
\hline
\end{tabular}

3. Rasio Efisiensi Keuangan Daerah (REKD) menggambarkan perbandingan antara besarnya biaya yang dikeluarkan untuk memperoleh pendapatan dengan realisasi pendapatan yang diterima. Rumus yang digunakan untuk menghitung rasio ini adalah sebagai berikut :

$$
\text { Rasio Efisiensi }=\frac{\text { Biaya yang dikeluarkan }}{\text { Realisasi Penerimaan PAD }} \times 100 \%
$$

Tabel 4.3

Kriteria Analisis Efisiensi Kinerja Keuangan 
Jurnal Progres Ekonomi Pembangunan (JPEP)

Volume 4, Nomor 2 , Tahun 2019

Page: $1-19$

http://ojs.uho.ac.id/index.php/JPEP

e-ISSN: 2052-5171

\begin{tabular}{|c|c|}
\hline $\begin{array}{c}\text { Persentase } \\
\text { Efisiensi }\end{array}$ & Kriteria Efisiensi \\
\hline$>100 \%$ & Tidak Efisien \\
\hline $90 \%-100 \%$ & Kurang Efisien \\
\hline $80 \%-90 \%$ & Cukup Efisien \\
\hline $60 \%-80 \%$ & Efisien \\
\hline$<60 \%$ & Sangat Efisien \\
\hline
\end{tabular}

Sumber : Muhammad Ikbar (2017)

4. Rasio Aktivitas Keuangan Daerah belum memiliki tolok ukur yang jelas saat ini, maka untuk membandingkan Rasio Aktivitas Keuangan Daerah pemerintah kabupaten/kota di Provinsi Sulawesi Tenggara, pada penelitian ini dilakukan penghitungan rata-rata belanja langsung dan belanja tidak langsung selama tahun penelitian (Susanthi dan Saftiana, 2010). Rasio Aktivitas Keuangan Daerah sendiri terdiri dari 2 rumus yaitu :

a) Belanja Langsung $=\frac{\text { Realisasi Penerimaan PAD }}{\text { Total } A P B D} \times 100 \%$

b) Belanja Tidak Langsung $=\frac{\text { Total Belanja Tidak Langsung }}{\text { Total } A P B D} \times 100 \%$

Rasio Aktivitas Keuangan Daerah dikatakan baik apabila APBD lebih banyak dialokasikan terhadap pengeluaran pembangunan atau belanja langsung dibanding pengeluaran rutin atau belanja tidak langsung (Rahmiyati,2008).

\section{Kemampuan Keuangan Daerah}

Rasio Derajat Otonomi Fiskal (DOF) perbandingan antara Pendapatan Asli Daerah (PAD) dengan Total Pendapatan Daerah (TPD), untuk meilhat seberapa keamampuan keuangan daerah dalam memenuhi kebutuhan dengan potensi daerah yang dimilik daerah tersebut. Rumus Rasio Derajat Otonomi Fiskal yaitu :

$$
\text { DOF }=\frac{\text { Pendapatan Asli Daerah }(P A D)}{\text { Total Pendapatan Daerah (TPD) }} \times 100 \%
$$

Tabel 4.4

Skala Interval Rasio Derajat Otonomi Fiskal 
Jurnal Progres Ekonomi Pembangunan (JPEP)

Volume 4, Nomor 2 , Tahun 2019

Page: $1-19$

http://ojs.uho.ac.id/index.php/JPEP

e-ISSN: 2052-5171

\begin{tabular}{|c|c|}
\hline Skala Interval & $\begin{array}{c}\text { Kemampuan } \\
\text { Keuangan Daerah }\end{array}$ \\
\hline $00,00-10,00$ & Sangat Kurang \\
\hline $10,01-20,00$ & Kurang \\
\hline $20,01-30,00$ & Cukup \\
\hline $30,01-40,00$ & Sedang \\
\hline $40,01-50,00$ & Baik \\
\hline$>50,00$ & Sangat Baik \\
\hline
\end{tabular}

Sumber Anita Wulandari (2001)

Penarikan kesimpulan kinerja keuangan pemerintah daerah dan kemampuan keuangan dapat dilihat dari trend rasio-rasio dalam kinerja keuangan pemerintah daerah dan kemampuan keuangan tiap entitas pada pemerintahan Provinsi Sulawesi Tenggara maka kinerja keuangan pemerintah daerah dan kemampuan keuangan pemerintah daerah kabupaten dan kota yang terdapat di provinsi tersebut dirata-rata untuk didapatkan hasil mengenai baik atau tidaknya kinerja keuangan pemerintah daerah dan kemampuan keuangan pemerintah daerah.

\section{HASIL DAN PEMBAHASAN}

Pengukuran kinerja keuangan dan kemampuan keuangan pada daerah Provinsi Sulawesi Tenggara dengan menggunakan rasio kemandirian keuangan, rasio efektivitas, rasio efisiensi, dan rasio aktivitas belanja, sedangkan untuk mengukur kemampuan keuangan dapat dilihat dengan menggunakan rasio derajat otonomi fiskal.

Hasil yang tercermin pada analisis beberapa rasio menggambarkan bahwa pada hampir semua daerah kabupaten/kota di Provinsi Sulawesi tenggara dalam hal kinerja keuangan dan kemampuan keuangan dapat dikatakan belum mampu dalam hal pelaksanaan otonomi daerah. Kebijakan Memoraterium untuk menunda pemekaran daerah di wilayah Indonesia khususnya Sulawesi Tenggara merupakan kebijakan yang tepat untuk menekan laju peningkatan pemekaran daerah daerah baru.

Tujuan utama dalam pelaksananaan otonomi daerah adalah salah satunya untuk mensejahterakan rakyat dan memberikan pelayanan yang baik kepada masyarakat, namun pada kenyataaanya banyak faktor kepentingan di dalam pelaksanaaan pemekaran hingga pelaksanaan otonomi daerah.

Tabel 3.1

Corresponding Author: Israwati Mustarim 10 
Jurnal Progres Ekonomi Pembangunan (JPEP)

Volume 4, Nomor 2 , Tahun 2019

Page: $1-19$

http://ojs.uho.ac.id/index.php/JPEP

Hasil Analisis Kinerja Keuangan dan Kemampuan Keuangan Daerah Induk

\begin{tabular}{|c|c|c|c|c|c|c|c|c|}
\hline \multirow{3}{*}{ Daerah } & \multirow{3}{*}{ No } & \multirow{3}{*}{ Tahun } & \multicolumn{4}{|c|}{ Kinerja Keuangan } & \multicolumn{2}{|c|}{ Kemampuan Keuangan } \\
\hline & & & \multirow{2}{*}{$\begin{array}{c}\text { Rasio } \\
\text { Kemandirian }\end{array}$} & \multirow{2}{*}{$\begin{array}{c}\text { Rasio } \\
\text { Efektivitas }\end{array}$} & \multicolumn{2}{|c|}{ Rasio Aktivitas } & \multirow[b]{2}{*}{ DOF } & \multirow[b]{2}{*}{ IKK } \\
\hline & & & & & $\begin{array}{c}\text { Belanja } \\
\text { Langsung }\end{array}$ & $\begin{array}{c}\text { Belanja Tidak } \\
\text { Langsung }\end{array}$ & & \\
\hline \multirow{7}{*}{$\begin{array}{c}\text { Provinsi } \\
\text { Sulawesi } \\
\text { Tenggara }\end{array}$} & 1 & 2011 & Konsultatif & Kurang Efektif & $47.31 \%$ & $52.69 \%$ & Cukup & Sangat Baik \\
\hline & 2 & 2012 & Konsultatif & Efektif & $32.16 \%$ & $67.84 \%$ & Cukup & Sangat Baik \\
\hline & 3 & 2013 & Konsultatif & Sangat Efektif & $41.51 \%$ & $58.49 \%$ & Cukup & Sangat Baik \\
\hline & 4 & 2014 & Konsultatif & Sangat Efektif & $46.66 \%$ & $53.34 \%$ & Cukup & Sangat Baik \\
\hline & 5 & 2015 & Konsultatif & Sangat Efektif & $47.41 \%$ & $52.59 \%$ & Cukup & Sangat Baik \\
\hline & 6 & 2016 & Konsultatif & Sangat Efektif & $44.94 \%$ & $55.06 \%$ & Cukup & Sangat Baik \\
\hline & 7 & 2017 & Konsultatif & Sangat Efektif & $31.23 \%$ & $65.82 \%$ & Cukup & Sangat Baik \\
\hline \multirow{7}{*}{$\begin{array}{c}\text { Kabupaten } \\
\text { Buton }\end{array}$} & 1 & 2011 & Instruktif & & $60.32 \%$ & $60.32 \%$ & Sangat Kurang & Sangat Baik \\
\hline & 2 & 2012 & Instruktif & Sangat Efektif & $60.96 \%$ & $60.96 \%$ & Sangat Kurang & Sangat Baik \\
\hline & 3 & 2013 & Instruktif & Sangat Efektif & $58.71 \%$ & $58.71 \%$ & Sangat Kurang & Sangat Baik \\
\hline & 4 & 2014 & Instruktif & Sangat Efektif & $58.11 \%$ & $58.11 \%$ & Sangat Kurang & Sangat Baik \\
\hline & 5 & 2015 & Instruktif & Sangat Efektif & $47.59 \%$ & $47.59 \%$ & Sangat Kurang & Sangat Baik \\
\hline & 6 & 2016 & Instruktif & Sangat Efektif & $48.30 \%$ & $48.30 \%$ & Sangat Kurang & Sangat Baik \\
\hline & 7 & 2017 & Instruktif & Sangat Efektif & $52.27 \%$ & $52.27 \%$ & Sangat Kurang & Sangat Baik \\
\hline \multirow{7}{*}{$\begin{array}{c}\text { Kabupaten } \\
\text { Muna }\end{array}$} & 1 & 2011 & Instruktif & & $64.92 \%$ & $35.08 \%$ & Sangat Kurang & Sangat Baik \\
\hline & 2 & 2012 & Instruktif & Cukup Efektif & $65.52 \%$ & $34.48 \%$ & Sangat Kurang & Sangat Baik \\
\hline & 3 & 2013 & Instruktif & Sangat Efektif & $61.21 \%$ & $38.79 \%$ & Sangat Kurang & Sangat Baik \\
\hline & 4 & 2014 & Instruktif & Sangat Efektif & $61.80 \%$ & $36.82 \%$ & Sangat Kurang & Sangat Baik \\
\hline & 5 & 2015 & Instruktif & Cukup Efektif & $59.00 \%$ & $39.78 \%$ & Sangat Kurang & Sangat Baik \\
\hline & 6 & 2016 & Instruktif & Cukup Efektif & $54.84 \%$ & $48.39 \%$ & Sangat Kurang & Sangat Baik \\
\hline & 7 & 2017 & Instruktif & Sangat Efektif & $59.33 \%$ & $40.67 \%$ & Sangat Kurang & Sangat Baik \\
\hline \multirow{7}{*}{$\begin{array}{c}\text { Kabupaten } \\
\text { Konawe }\end{array}$} & 1 & 2011 & Instruktif & & $60.32 \%$ & $60.32 \%$ & Sangat Kurang & Sangat Baik \\
\hline & 2 & 2012 & Instruktif & Sangat Efektif & $60.96 \%$ & $60.96 \%$ & Sangat Kurang & Sangat Baik \\
\hline & 3 & 2013 & Instruktif & Sangat Efektif & $58.71 \%$ & $58.71 \%$ & Sangat Kurang & Sangat Baik \\
\hline & 4 & 2014 & Instruktif & Sangat Efektif & $58.11 \%$ & $58.11 \%$ & Sangat Kurang & Sangat Baik \\
\hline & 5 & 2015 & Instruktif & Kurang Efektif & $47.59 \%$ & $47.59 \%$ & Sangat Kurang & Sangat Baik \\
\hline & 6 & 2016 & Instruktif & Efektif & $48.30 \%$ & $48.30 \%$ & Sangat Kurang & Sangat Baik \\
\hline & 7 & 2017 & Instruktif & Kurang Efektif & $52.27 \%$ & $52.27 \%$ & Sangat Kurang & Sangat Baik \\
\hline \multirow{8}{*}{$\begin{array}{c}\text { Kabupaten } \\
\text { Kolaka }\end{array}$} & 1 & 2011 & Instruktif & & $42.36 \%$ & $57.64 \%$ & Sangat Kurang & Sangat Baik \\
\hline & 2 & 2012 & Instruktif & Tidak Efektif & $46.93 \%$ & $53.07 \%$ & Sangat Kurang & Sangat Baik \\
\hline & 3 & 2013 & Instruktif & Sangat Efektif & $44.44 \%$ & $55.56 \%$ & Sangat Kurang & Sangat Baik \\
\hline & 4 & 2014 & Instruktif & Sangat Efektif & $47.68 \%$ & $52.32 \%$ & Sangat Kurang & Sangat Baik \\
\hline & 5 & 2015 & Instruktif & Sangat Efektif & $5.67 \%$ & $45.59 \%$ & Sangat Kurang & Sangat Baik \\
\hline & 6 & 2016 & Instruktif & Efektif & $50.73 \%$ & $49.27 \%$ & Sangat Kurang & Sangat Baik \\
\hline & 7 & 2017 & Instruktif & Sangat Efektif & $32.14 \%$ & $67.86 \%$ & Kurang & Sangat Baik \\
\hline & 1 & 2011 & Instruktif & & $42.36 \%$ & $34.49 \%$ & Sangat Kurang & Sangat Baik \\
\hline \multirow{6}{*}{ Kota Kendari } & 2 & 2012 & Instruktif & Efektif & $46.93 \%$ & $104.23 \%$ & Sangat Kurang & Sangat Baik \\
\hline & 3 & 2013 & Instruktif & Sangat Efektif & $44.44 \%$ & $107.85 \%$ & Sangat Kurang & Sangat Baik \\
\hline & 4 & 2014 & Instruktif & Tidak Efektif & $47.68 \%$ & $48.80 \%$ & Kurang & Sangat Baik \\
\hline & 5 & 2015 & Instruktif & Tidak Efektif & $56.70 \%$ & $48.49 \%$ & Kurang & Sangat Baik \\
\hline & 6 & 2016 & Instruktif & Kurang Efektif & $50.73 \%$ & $52.54 \%$ & Kurang & Sangat Baik \\
\hline & 7 & 2017 & Konsultatif & Kurang Efektif & $32.14 \%$ & $51.63 \%$ & Kurang & Sangat Baik \\
\hline \multirow{7}{*}{ Kota Bau Bau } & 1 & 2011 & Instruktif & & $34.49 \%$ & $65.51 \%$ & Sangat Kurang & Sangat Baik \\
\hline & 2 & 2012 & Instruktif & Sangat Efektif & $104.23 \%$ & $65.51 \%$ & Sangat Kurang & Sangat Baik \\
\hline & 3 & 2013 & Instruktif & Sangat Efektif & $107.85 \%$ & $56.44 \%$ & Sangat Kurang & Sangat Baik \\
\hline & 4 & 2014 & Instruktif & Sangat Efektif & $48.80 \%$ & $51.20 \%$ & Sangat Kurang & Sangat Baik \\
\hline & 5 & 2015 & Instruktif & Sangat Efektif & $48.49 \%$ & $51.51 \%$ & Sangat Kurang & Sangat Baik \\
\hline & 6 & 2016 & Instruktif & Sangat Efektif & $52.54 \%$ & $47.46 \%$ & Sangat Kurang & Sangat Baik \\
\hline & 7 & 2017 & Instruktif & Sangat Efektif & $51.63 \%$ & $48.37 \%$ & Kurang & Sangat Baik \\
\hline
\end{tabular}

Sumber : Data Sekunder, (diolah, 2018)

Gambaran hasil kinerja keuangan dan kemampuan keuangan pada Kabupaten/Kota di Provinsi Sulawesi Tenggara mencerminkan kegagalan dalam pelaksanaan otonomi daerah. Kinerja 
Jurnal Progres Ekonomi Pembangunan (JPEP)

Volume 4, Nomor 2 , Tahun 2019

Page: $1-19$

http://ojs.uho.ac.id/index.php/JPEP

keuangan pada daerah induk sebagian besar menghasilkan bahwa daerah masih sangat tergantung pada dana Pemerintah pusat.

Kinerja keuangan dilihat dari rasio kemandirian keuangan pada kabupaten/kota induk mengindikasikan sebagian besar atau mayoritas masih berada pada pola hubungan instruktif, dimana pemerintah daerah dianggap belum mampu secara mandiri dalam membiayai pemerintahannya, sedangkan rasio efektivitas untuk sebagian besar sangat efektif, hanya ada beebrapa daerah saja yang belum efketif atau kuang efektif dalam pengelolaan keuangan. Rasio aktivitas menunjukkan bahwa baik dalam belanja langsung maupun tidak langsung mencerminkan dana digunakan untuk belanja operssional pemerintah, sedangkan untuk pelayanan publik masih sangat minim.

Kemampuan keuangan pada kabupaten/kota di Provinsi Sulawesi Tenggara berada pada kategori kurang mampu dalam membiayai penyelenggaraan pemerintah. Ketergantungan akan dana bantuan pusat mencerminkan bahwa optimalisasi sumber daya daerah dan pengelolaannya masih sangat terbatas. Hal ini menandakan bahwa kinerja keuangan dan kemampuan keuangan pemerintah daerah dalam hal otonomi daerah tidak terlaksana dengan semestinya.

Tabel 3.2

Hasil Analisis Kinerja Keuangan dan Kemampuan Keuangan DOB diatas 5 Tahun

\begin{tabular}{|c|c|c|c|c|c|c|c|c|}
\hline \multirow{10}{*}{$\begin{array}{c}\text { Kabupaten } \\
\text { Konawe } \\
\text { Selatan }\end{array}$} & \multirow{3}{*}{ No } & \multirow{3}{*}{ Tahun } & \multicolumn{4}{|c|}{ Kinerja Keuangan } & \multicolumn{2}{|c|}{ Kemampuan Keuangan } \\
\hline & & & \multirow{2}{*}{$\begin{array}{c}\text { Rasio } \\
\text { Kemandirian }\end{array}$} & \multirow{2}{*}{$\begin{array}{c}\text { Rasio } \\
\text { Efektivitas }\end{array}$} & \multicolumn{2}{|c|}{ Rasio Aktivitas } & \multirow[b]{2}{*}{ DOF } & \multirow[b]{2}{*}{ IKK } \\
\hline & & & & & $\begin{array}{c}\text { Belanja } \\
\text { Langsung }\end{array}$ & $\begin{array}{l}\text { Belanja Tidak } \\
\text { Langsung }\end{array}$ & & \\
\hline & 1 & 2011 & Instruktif & & $57.95 \%$ & $42.05 \%$ & Sangat Kurang & Sangat Baik \\
\hline & 2 & 2012 & Instruktif & Sangat Efektif & $53.60 \%$ & $46.40 \%$ & Sangat Kurang & Sangat Baik \\
\hline & 3 & 2013 & Instruktif & Sangat Efektif & $48.06 \%$ & $51.94 \%$ & Sangat Kurang & Sangat Baik \\
\hline & 4 & 2014 & Instruktif & Sangat Efektif & $48.49 \%$ & $51.51 \%$ & Sangat Kurang & Sangat Baik \\
\hline & 5 & 2015 & Instruktif & Sangat Efektif & $57.27 \%$ & $42.73 \%$ & Sangat Kurang & Sangat Baik \\
\hline & 6 & 2016 & Instruktif & Sangat Efektif & $62.52 \%$ & $37.48 \%$ & Sangat Kurang & Sangat Baik \\
\hline & 7 & 2017 & Instruktif & Sangat Efektif & $81.58 \%$ & $18.29 \%$ & Sangat Kurang & Sangat Baik \\
\hline \multirow{7}{*}{$\begin{array}{l}\text { Kabupaten } \\
\text { Bombana }\end{array}$} & 1 & 2011 & Instruktif & & $50.67 \%$ & $49.33 \%$ & Sangat Kurang & Sangat Baik \\
\hline & 2 & 2012 & Instruktif & Sangat Efektif & $50.93 \%$ & $49.07 \%$ & Sangat Kurang & Sangat Baik \\
\hline & 3 & 2013 & Instruktif & Sangat Efektif & $43.52 \%$ & $56.48 \%$ & Sangat Kurang & Sangat Baik \\
\hline & 4 & 2014 & Instruktif & Sangat Efektif & $38.84 \%$ & $61.16 \%$ & Sangat Kurang & Sangat Baik \\
\hline & 5 & 2015 & Instruktif & Kurang Efektif & $47.35 \%$ & $52.65 \%$ & Sangat Kurang & Sangat Baik \\
\hline & 6 & 2016 & Instruktif & Kurang Efektif & $49.43 \%$ & $50.57 \%$ & Sangat Kurang & Sangat Baik \\
\hline & 7 & 2017 & Instruktif & Sangat Efektif & $34.14 \%$ & $134.39 \%$ & Sangat Kurang & Sangat Baik \\
\hline \multirow{7}{*}{$\begin{array}{c}\text { Kabupaten } \\
\text { Wakatobi }\end{array}$} & 1 & 2011 & Instruktif & & $55.25 \%$ & $44.75 \%$ & Sangat Kurang & Sangat Baik \\
\hline & 2 & 2012 & Instruktif & Sangat Efektif & $54.21 \%$ & $45.79 \%$ & Sangat Kurang & Sangat Baik \\
\hline & 3 & 2013 & Instruktif & Sangat Efektif & $58.48 \%$ & $41.52 \%$ & Sangat Kurang & Sangat Baik \\
\hline & 4 & 2014 & Instruktif & Efektif & $55.89 \%$ & $44.11 \%$ & Sangat Kurang & Sangat Baik \\
\hline & 5 & 2015 & Instruktif & Cukup Efektif & $54.73 \%$ & $45.27 \%$ & Sangat Kurang & Sangat Baik \\
\hline & 6 & 2016 & Instruktif & Efektif & $52.16 \%$ & $47.84 \%$ & Sangat Kurang & Sangat Baik \\
\hline & 7 & 2017 & Instruktif & Sangat Efektif & $32.04 \%$ & $67.96 \%$ & Sangat Kurang & Sangat Baik \\
\hline \multirow{3}{*}{$\begin{array}{c}\text { Kabupaten } \\
\text { Kolaka } \\
\text { Utara } \\
\end{array}$} & 1 & 2011 & Instruktif & & $59.44 \%$ & $40.56 \%$ & Sangat Kurang & Sangat Baik \\
\hline & 2 & 2012 & Instruktif & Tidak Efektif & $55.06 \%$ & $44.94 \%$ & Sangat Kurang & Sangat Baik \\
\hline & 3 & 2013 & Instruktif & Sangat Efektif & $60.73 \%$ & $39.27 \%$ & Sangat Kurang & Sangat Baik \\
\hline
\end{tabular}




\section{Jurnal Progres Ekonomi Pembangunan (JPEP) \\ Volume 4, Nomor 2 , Tahun 2019 \\ Page: $1-19$ \\ http://ojs.uho.ac.id/index.php/JPEP}

e-ISSN: 2052-5171

\begin{tabular}{|c|c|c|c|c|c|c|c|c|}
\hline & 4 & 2014 & Instruktif & Sangat Efektif & $62.39 \%$ & $37.61 \%$ & Sangat Kurang & Sangat Baik \\
\hline & 5 & 2015 & Instruktif & Sangat Efektif & $59.64 \%$ & $40.36 \%$ & Sangat Kurang & Sangat Baik \\
\hline & 6 & 2016 & Instruktif & Efektif & $54.63 \%$ & $45.37 \%$ & Sangat Kurang & Sangat Baik \\
\hline & 7 & 2017 & Instruktif & Sangat Efektif & $41.56 \%$ & $58.44 \%$ & Sangat Kurang & Sangat Baik \\
\hline \multirow{7}{*}{$\begin{array}{c}\text { Kabupaten } \\
\text { Kabupaten } \\
\text { Buton } \\
\text { Utara }\end{array}$} & 1 & 2011 & Instruktif & & $70.16 \%$ & $29.84 \%$ & Sangat Kurang & Sangat Baik \\
\hline & 2 & 2012 & Instruktif & Sangat Efektif & $66.72 \%$ & $33.28 \%$ & Sangat Kurang & Sangat Baik \\
\hline & 3 & 2013 & Instruktif & Sangat Efektif & $70.58 \%$ & $29.42 \%$ & Sangat Kurang & Sangat Baik \\
\hline & 4 & 2014 & Instruktif & Sangat Efektif & $68.91 \%$ & $31.09 \%$ & Sangat Kurang & Sangat Baik \\
\hline & 5 & 2015 & Instruktif & Sangat Efektif & $59.71 \%$ & $40.29 \%$ & Sangat Kurang & Sangat Baik \\
\hline & 6 & 2016 & Instruktif & Efektif & $60.78 \%$ & $39.22 \%$ & Sangat Kurang & Sangat Baik \\
\hline & 7 & 2017 & Instruktif & Cukup Efektif & $56.18 \%$ & $43.82 \%$ & Sangat Kurang & Sangat Baik \\
\hline \multirow{7}{*}{$\begin{array}{c}\text { Kabupaten } \\
\text { Konawe } \\
\text { Utara }\end{array}$} & 1 & 2011 & Instruktif & & $68.56 \%$ & $31.44 \%$ & Kurang & Sangat Baik \\
\hline & 2 & 2012 & Instruktif & Tidak Efektif & $67.64 \%$ & $32.36 \%$ & Sangat Kurang & Sangat Baik \\
\hline & 3 & 2013 & Instruktif & Tidak Efektif & $72.21 \%$ & $27.79 \%$ & Sangat Kurang & Sangat Baik \\
\hline & 4 & 2014 & Instruktif & Tidak Efektif & $73.76 \%$ & $26.24 \%$ & Sangat Kurang & Sangat Baik \\
\hline & 5 & 2015 & Instruktif & Tidak Efektif & $62.12 \%$ & $37.88 \%$ & Sangat Kurang & Sangat Baik \\
\hline & 6 & 2016 & Instruktif & Sangat Efektif & $57.92 \%$ & $42.08 \%$ & Sangat Kurang & Sangat Baik \\
\hline & 7 & 2017 & Instruktif & Sangat Efektif & $52.11 \%$ & $47.89 \%$ & Sangat Kurang & Sangat Baik \\
\hline
\end{tabular}

Sumber : Data sekunder, (diolah, 2018)

Tabel 3.3

\section{Hasil Analisis Kinerja Keuangan dan Kemampuan Keuangan DOB dibawah 5 Tahun}

\begin{tabular}{|c|c|c|c|c|c|c|c|c|}
\hline \multirow{10}{*}{$\begin{array}{c}\text { Kabupaten } \\
\text { Kolaka } \\
\text { Timur }\end{array}$} & \multirow{3}{*}{ No } & \multirow{3}{*}{ Tahun } & \multicolumn{4}{|c|}{ Kinerja Keuangan } & \multicolumn{2}{|c|}{ Kemampuan Keuangan } \\
\hline & & & \multirow{2}{*}{$\begin{array}{c}\text { Rasio } \\
\text { Kemandirian }\end{array}$} & \multirow{2}{*}{$\begin{array}{c}\text { Rasio } \\
\text { Efektivitas }\end{array}$} & \multicolumn{2}{|c|}{ Rasio Aktivitas } & \multirow[b]{2}{*}{ DOF } & \multirow[b]{2}{*}{ IKK } \\
\hline & & & & & $\begin{array}{c}\text { Belanja } \\
\text { Langsung }\end{array}$ & $\begin{array}{c}\text { Belanja Tidak } \\
\text { Langsung }\end{array}$ & & \\
\hline & 1 & 2011 & & & - & - & & \\
\hline & 2 & 2012 & & & - & - & - & - \\
\hline & 3 & 2013 & & & - & - & - & - \\
\hline & 4 & 2014 & Instruktif & Sangat Efektif & $54.51 \%$ & $45.49 \%$ & Sangat Kurang & Sangat Baik \\
\hline & 5 & 2015 & Instruktif & Sangat Efektif & $57.09 \%$ & $42.91 \%$ & Sangat Kurang & Sangat Baik \\
\hline & 6 & 2016 & Instruktif & Sangat Efektif & $54.01 \%$ & $45.99 \%$ & Sangat Kurang & Sangat Baik \\
\hline & 7 & 2017 & Instruktif & Sangat Efektif & $40.87 \%$ & $31.93 \%$ & Sangat Kurang & Sangat Baik \\
\hline \multirow{7}{*}{$\begin{array}{l}\text { Kabupaten } \\
\text { Konawe } \\
\text { Kepulauan }\end{array}$} & 1 & 2011 & & & - & - & - & - \\
\hline & 2 & 2012 & & - & - & - & - & - \\
\hline & 3 & 2013 & & - & - & - & - & - \\
\hline & 4 & 2014 & & - & - & - & - & - \\
\hline & 5 & 2015 & Instruktif & Kurang Efektif & $75.80 \%$ & $24.20 \%$ & Sangat Kurang & Sangat Baik \\
\hline & 6 & 2016 & Instruktif & Kurang Efektif & $75.28 \%$ & $24.72 \%$ & Sangat Kurang & Sangat Baik \\
\hline & 7 & 2017 & Instruktif & Kurang Efektif & $58.12 \%$ & $41.76 \%$ & Sangat Kurang & Sangat Baik \\
\hline \multirow{7}{*}{$\begin{array}{l}\text { Kabupaten } \\
\text { Muna Barat }\end{array}$} & 1 & 2011 & & - & - & - & - & - \\
\hline & 2 & 2012 & & - & - & - & - & - \\
\hline & 3 & 2013 & & - & - & - & - & - \\
\hline & 4 & 2014 & & - & - & - & - & - \\
\hline & 5 & 2015 & Instruktif & Sangat Efektif & $64.48 \%$ & $35.52 \%$ & Sangat Kurang & Sangat Baik \\
\hline & 6 & 2016 & Instruktif & Sangat Efektif & $52.46 \%$ & $47.54 \%$ & Sangat Kurang & Sangat Baik \\
\hline & 7 & 2017 & Instruktif & Kurang Efektif & $62.79 \%$ & $37.21 \%$ & Sangat Kurang & Sangat Baik \\
\hline \multirow{4}{*}{$\begin{array}{c}\text { Kabupaten } \\
\text { Buton } \\
\text { Tengah }\end{array}$} & 1 & 2011 & & - & - & - & - & - \\
\hline & 2 & 2012 & & - & - & - & - & - \\
\hline & 3 & 2013 & & - & - & - & - & - \\
\hline & 4 & 2014 & & - & - & - & - & - \\
\hline
\end{tabular}


Jurnal Progres Ekonomi Pembangunan (JPEP)

Volume 4, Nomor 2 , Tahun 2019

Page: $1-19$

http://ojs.uho.ac.id/index.php/JPEP

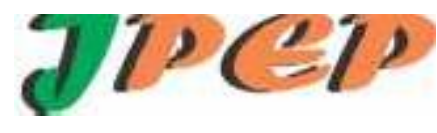

e-ISSN: 2052-5171

\begin{tabular}{|c|c|c|c|c|c|c|c|c|}
\hline & 5 & 2015 & Instruktif & - & $47.30 \%$ & $52.70 \%$ & Sangat Kurang & Sangat Baik \\
\hline & 6 & 2016 & Instruktif & Sangat Efektif & $56.92 \%$ & $43.08 \%$ & Sangat Kurang & Sangat Baik \\
\hline & 7 & 2017 & Instruktif & Sangat Efektif & $57.66 \%$ & $42.34 \%$ & Sangat Kurang & Sangat Baik \\
\hline \multirow{7}{*}{$\begin{array}{c}\text { Kabupaten } \\
\text { Buton } \\
\text { Selatan }\end{array}$} & 1 & 2011 & & - & - & - & - & - \\
\hline & 2 & 2012 & & - & - & - & - & - \\
\hline & 3 & 2013 & & - & - & - & - & - \\
\hline & 4 & 2014 & & - & - & - & - & - \\
\hline & 5 & 2015 & Instruktif & - & $34.14 \%$ & $65.86 \%$ & Sangat Kurang & Sangat Baik \\
\hline & 6 & 2016 & Instruktif & Sangat Efektif & $49.20 \%$ & $50.80 \%$ & Sangat Kurang & Sangat Baik \\
\hline & 7 & 2017 & Instruktif & Sangat Efektif & $56.52 \%$ & $43.48 \%$ & Sangat Kurang & Sangat Baik \\
\hline
\end{tabular}

Sumber : Data Sekunder, diolah 2018

Kinerja Keuangan Pemerintah Daerah Kabupaten/Kota Provinsi Sulawesi Tenggara

Kinerja keuangan pemerintah daerah Provinsi Sulawesi Tenggara diukur berdasarkan rasio kemandirian keuangan daerah, rasio efektivitas keuangan, rasio aktivitas belanja.

1. Kinerja Keuangan dilihat dari Rasio Kemandirian Keuangan Daerah Provinsi Sulawesi Tenggara

Berdasarkan analisis kinerja keuangan pemeritnah daerah pada 18 (delapan belas) entitas di Kabupaten/Kota Provinsi Sulawesi Tenggara mengalami trend yang berfluktuatif selama kurun waktu 2011 s.d 2017. Hasil rasio kemandirian baik untuk daerah induk, pemekaran diatas 5 tahun dan daerah otonomi baru menggambarkan secara garis besar kemampuan keuangan daerah yang masih sangat rendah (nilai persentase berada pada kisaran 0\%-25\%) sehingga masuk pada pola hibingan Isntruktif diamana ketergantungan akan dana dari pihak eskternal masihsangat tinggi. Sesuai dengan teori yang dikemukakan oleh Abdul Halim (2007) rasio kemandirian keuagan daerah (RKKPD) dibawah 25\% memiliki kemampuan keuangan yang rendah sekali dengan pola hubungan pemeritah pusat dan daerah bersifat isntruktif.

Hasil penelitian ini tidak jauh berbeda dengan penelitian Amriati Sambo (2013) tentang analisis indikator kinerja pengelolaaan keuangan daerah Provinsi Sulawesi Tenggara yang menjelaskan bahwa membiayai penyelenggraan otonomi daerah pemerintah Provinsi Sulawesi Tenggara mengalami trend fluktuasi dengan rata-rata sebesar $3.73 \%$ sehingga masuk dalam kategori rendah berada dalam kategori 25\%-50\% hal ini bersifat konsklusif, yaitu campur tanan pemerintah pusat sudah mulai berkurang karena daerah dianggap lebih sedikit mampu melaksanakan otonomi daerah. Pada penilitan ini fokus pada pemerintahan Provinsi Sulawesi Tenggara sedangkan peneliti mengambil keseluruhan kabupaten/kota termaksud entitas Provinsi Sulawesi Tenggara sebagai objek penelitian.

2. Kinerja Keuangan dinilai dari Rasio Efektivitas PAD

Rasio efektivitas menggambarkan kemampuan pemerintah daerah Provinsi Sualwesi Tenggara dalam merealisasikan pendapatan asli daerah pada sebagian daerah kabupaten/kota sudah efektif, namun ada beberapa daerah juga yang dikategorikan cukup efektif dan bahkan 
Jurnal Progres Ekonomi Pembangunan (JPEP)

Volume 4, Nomor 2 , Tahun 2019

Page: $1-19$

http://ojs.uho.ac.id/index.php/JPEP

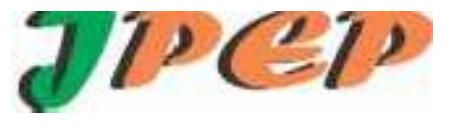

e-ISSN: 2052-5171

kurang efektif. Rata- rata nilai rasio efektivitas PAD berada pada nilai $74 \%$ atau diperoleh dalam kategori $60 \%$ s.d $80 \%$.

Beni Pekei (2016) mengungkapkan bahwa rasio antara 60\% sampai dengan $80 \%$ masuk dalam kriteria kurang efektif. Hal ini menunjukkan bahwa pemerintah daerah Provinsi Sulawesi Tenggara masuk dalam kategori kurang efektif.

Sejalan dengan penelitian yang dilakukan Gregius Gebi Batfor (2011) dalam tesisnya "Evaluasi kinerja keuangan dan tingkat kesejahteraan masyarakat Kabupaten Lembata Provinsi Nusa Tenggara Timur" mengungkapkan bahwa tingkat efisiensi pengelolaan keuanga daerah periode pertama lebih iefisien dibadningkan dengan tingkat efisiesni di period e kedua.

3. Kinerja Keuangan dilihat dari Rasio Aktivitas

Berdasarkan penelitian yang telah dilakukan kmenujukkan bahwa kinerja keuangan pemerintah daerah induk menitik beratkan alokasi dana lebih dari 50\% pada alokasi belanja tidak langsung sedangkan pada daerah otonom baik yang pelaksanaanya diatas 5 tahun maupun yang dibawah 5 tahun mendapatkan hasil yang berbeda, yaitu persentase untuk belanja tidak langsung dibawah 50\%. Daerah otonom lebih menitikberatkan alokasi dana untuk peningkatan pelayanan publik melalui pembangunan infrsktruktur yang dapat meningkatkan sektor perekonomian masyarakat.

Patokan yang pasti belum ada untuk menentukan berapa besarnya rasio belanja langsung maupun tidak langsung karena sangat dipengaruhi oleh dinamika kegiatan pembangunan dan besarnya kebutuhan investasi yang diperlukan untuk mencapai pertumbuhan yang diatrgetkan (Abdul Halim, 2012).

Penelitian ini berbeda dengan penelitian sangjaya (2007), peningkatan kebutuhan fiskal sesudah otonomi daerah lebih dikarenakan terdapat beberapa kewenangan dan kebutuhan daerah yang sebelum otonomi daerah ditangani oleh pemerintah pusat, setelah otonomi daerah harus ditangani oleh pemerintah daerah, seperti pengalihan gaji pegawai negeri yang pada saat sebelum otonomi daerah dibebankan oleh APBD, sedangkan belanja layanan publik pemerintah daerah cendrung tidak mengalami kenaikan yang berarti. Hal ini mengidentifikasikan bahwa setelah otonomi daerah masih belum bisa meningkatkan kinerja dalam melaksanakan berbagai aktifitas pelayanan publik.

5.5.2 Kemampuan Keuangan Pemerintah Daerah Kabupaten/Kota Provinsi Sulawesi Tenggara Berdasarkan analisis kinerja keuangan pemerintah darah Kabupaten/Kota Provinsi Sulawesi Tenggara dilihat dari derajat otonomi fiskal dan indeks kemampuan keuangan. Derajat Otonomi Fiskal diketahi bahwa pada umumnya skala interval dof untuk kabupaten/kota di Provinsi Sulawesi Tenggara masih sangat rendah, dan berada pata kategori Sangat kurang.

Hasil analisis ini sesuai dengan pendapat TIM FISPOL UGM skala interval derajat desentralisasi fiskal rata rata dibawah $10 \%$ sehingga masuk dalam ategori kemampuan keuangans sangat kurang dengan rata-ratas ebesar 3,64\% maka hal ini dapat dikatakan bawha untk melaksanakan tugas tugas pemerintahan, pembangunan dan pelayanan masyarakat masih sangat kurang sehingga memiliki ketergantungan tinggi terhadp bantuan pemerintah puat melalui dana perimbangan dalam melaksanakanotonomi daerah, sehinggga kesimpullan bahwa pelaksanaan otonomi daerah di Kabupaten/kota Provinsi Sualwesi Tenggara tidak berhasil.

Hasil studi ini sejalan dengan hasil studi yang dilakukan Anwar (2010), meneliti tentang analisis kinerja pengelolaan keuangan daerah kota Kendari, berdasarkan hasil penelitin ini digambarkan bahwa kemandirian keuangan daerah kota Kendari dalam membiayai otonomi 
Jurnal Progres Ekonomi Pembangunan (JPEP)

Volume 4, Nomor 2 , Tahun 2019

Page: $1-19$

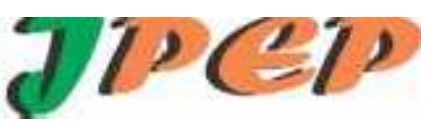

http://ojs.uho.ac.id/index.php/JPEP

e-ISSN: 2052-5171

daerah belum mandiri, diman desentralisasi fiskal merupakan kewenangan dari emerintah daerah untuk mengatur pembelanjaan atau pengeluaran pengeluaran keuangan daerah dan bagaimana pemerintah daerah mengelola oendapatan daerah dalam rangka membiayai pengeluran atau belanja daerah tersebut untuk membiayai keiatan pemerintah daerah berdasarkan komponen utama dari desentralisasi.

Indeks Kemampuan Keuangan untuk pemerintahan daerah Provinsi Sulawesi Tenggara mendpatkan hasil analisa yang berbeda dimana kemampuan keuangan pada Provinsi Sulawesi Tengara terlihat sangat baik, namun yang menjadi fokus dalam pengukuran penilaian ini adalah total pendapatan darah membiayai belanja daerah sehingga daerah dianggap mampu dalam hal pembiayaan belanja daerah. Namun yang perlu diketahui adalah dalam total pendapatan daerah tidak semua pendapatan berasal dari PAD, sehingga analiss dengan meggunakan Indeks kemampuan Keuangan tidak menjadi patokan utama dalam penialaian kemampuan keuangan sebuah daerah.

\section{KESIMPULAN}

Berdasarkan hasil peneliitan analisis rasio dan pembahasan yang telah diuraikan dapat ditarik kesimpulan bahwa dalam Pelaksanaan Otonomi daerah Pemerintah Kabupaten/Kota Provinsi Sulawesi Tenggara selama kurun wkatu 2011 s.d 2017 adalah sebagai berikut :

1. Kinerja keuangan pemerintah daerah di Provinsi Sulawesi Tenggara menggambarkan kemandirian kemampuan keuangan daerah yang sangat rendah dan masuk pada pola hubungan instruktif, dimana kecenderungan atas dana eksternal sangat tinggi. Pengelolaan efektivitas PAD cenderung sangat baik karena PAD yang telah ditargetkan tercapai. Sedangkan untuk aktivitas belanja berbeda antara daerah induk dan daerah otonom, dimana daerah induk mengalokasikan dananya diatas $50 \%$ untuk belanja tidak langsung sedangkan daerah otonom baik yang pelaksananya diatas 5 tahun maupun daerah otonom baru mengindikasikan bahwa belanja langsung mendapatkan porsi lebih dari $50 \%$.

2. Kemamapuan keuangan pemerintah daerah di Provinsi Sulawesi Tenggara dari penilaian rasio derajat otonomi fiskal mendpatkan hasil bahwa baik daerah induk maupun daerah otonom mendapakan hasil kemampuan keuangan yang kurang, hal ini berarti pelaksanaan pemerintahan masih sangat ketergantungan oleh dana pemerintah pusat. Sehingga pelaksanaan otonomi daerah dinilai tidak berjalan dengan baik. Penilaian indeks kemampuan keuangan menampilkan hasil sangat baik, karena belanja daerah mampu terpenuhi dari total pendapatan daerah . tetapi yang menjadi fokus kemampuan keuangan ini bukan menjadi patokan utama karena pada rasio sebelumnya diketahui bahwa penerimaan daerah bukan hanya berasal dari PAD melainkan sebagian besar berasal dari dana talangan pusat.

\section{DAFTAR PUSTAKA}


Jurnal Progres Ekonomi Pembangunan (JPEP)

Volume 4, Nomor 2 , Tahun 2019

Page: 1-19

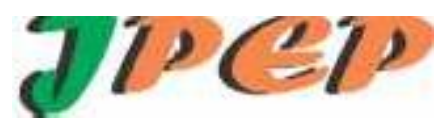

http://ojs.uho.ac.id/index.php/JPEP

e-ISSN: 2052-5171

Adisubrata, Winarna Surya. 2003. Perkembangan Otonomi Daerah Di Indonesia. Semarang: CV Aneka Ilmu.

Badan Pusat Statistik, Sulawesi Tenggara Dalam Angka 2011: BPS Provinsi Sulawesi Tenggara, 2011

Tenggara, 2012

Sulawesi Tenggara Dalam Angka 2012: BPS Provinsi Sulawesi

, Sulawesi Tenggara Dalam Angka 2013: BPS Provinsi Sulawesi

Tenggara, 2013

2014

, Sulawesi Tenggara Dalam Angka 2014: BPS Provinsi Sulawes Tenggara, , Sulawesi Tenggara Dalam Angka 2015: BPS Provinsi Sulawes Tenggara, 2015

2016

, Sulawesi Tenggara Dalam Angka 2016: BPS Provinsi Sulawes Tenggara,

Budi Aji, Baskoro dan Tristiarii, Nita. 2015. Analisis Kinerja Keuangan pada Dinas Pengelolaan Keuangan dan Aset Daerah (DPKAD) Kota Semarang Tahun 2012-2014. Skripsi, Universitas Dian Nuswantoro.

Dajan, Anton. 1991. Pengantar Metode Statistik.Jakarta : LP3FS.

Davey, K.J, 1988. Pembiayaan Pemerintah Daerah. Jakarta : PT. Gramedia Pustaka Utama.

Dora, Juliani (2017) Analisis kinerja keuangan Daerah Pemerintah Kota Yogyakarta tahun 2010-2014. Tesis, Sanata Dharma University.

Halim, Abdul. 2004. Akuntansi Keuangan Daerah, Edisi Revisi. Jakarta: Salemba Empat.

Halim, Abdul. 2007. Akuntansi Sektor Publik Akuntansi keuangan daerah, Edisi Revisi, Jakarta, Salemba Empat.

Halim, Abdul. 2008. Akuntansi Keuangan Daerah Edisi 3. Yogyakarta: Penerbit Salemba Empat.

Ikbar, Muhammad. 2017. Analisis Kinerja Keuangan Pemerintah Daerah Kabupaten Bombana. Tesis, Universitas Halu Oleo. 
Jurnal Progres Ekonomi Pembangunan (JPEP)

Volume 4, Nomor 2 , Tahun 2019

Page: $1-19$

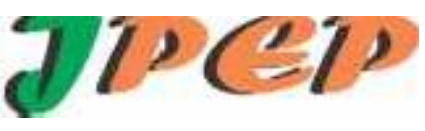

http://ojs.uho.ac.id/index.php/JPEP

e-ISSN: 2052-5171

Kaho. 1998. Prospek Otonomi Daerah di Negara Republik Indonesia, Raja Grafindo Persada, Jakarta.

Kuncoro, Mudrajad. 2000. Ekonomi Pembangunan: Teori, Masalah dan Kebijakan, UPP AMP YKPN.

Manulang, H. Sendjun. 1995. Pokok-Pokok Hukum Ketenagakerjaan di Indonesia. Jakarta : PT Rineka Cipta.

Mardiasmo. 2002. Otonomi dan Manajemen Keuangan Daerah. Yogyakarta: Andhi.

Mardiasmo. 2002. Akuntansi Sektor Publik. Penerbit Andi. Yogyakarta.Mamesah, D, J. 1995. Sistem Administrasi Keuangan Daerah. Jakarta: Pustaka Utama.

Mudrajad Kuncoro. 2007. Metode Riset Untuk Bisnis dan Ekonomi, Erlangga Jakarta.

Nataluddin. 2001. Potensi dana perimbangan daerah pada pemerintah daerah di Propinsi Jambi, Manajemen Keuangan Daerah. Yogyakarta: UPP YKPN.

Peraturan Pemerintah No. 105 tahun 2000.

Rahmiyati, Sri. 2008. Keefektifan pemanfaatan laboratorium di Madrasah Aliyah Yogyakarta. Yogyakarta: Jurnal penelitian dan evaluasi pendidikan (1): hal-96.

Safi'i, H.M 2007. Strategi dan Kebijakan Pembangunan Ekonomi Daerah. Malang : Averroe Press.

Sedarmayanti. 2003. Dasar - Dasar penegtahuan tentang Manajemen Perkantoran. Bandung: Mandar Maju.

Susilo, Gideon Tri Budi dan Hariadi, Priyo. 2007. Analisis Kinerja Keuangan Daerah Sebelum Dan Sesudah Otonomi (Studi Empiris Di Propinsi Jawa Tengah). Konferensi Penelitian Akuntansi Dan Keuangan Sektor Publik Pertama, 25-26 April 2007.

Syamsi, Ibnu, 1986. Pokok-Pokok Kebijaksanaan, Perencanaan, Pemrograman, dan Penganggaran Pembangunan Tingkat Nasional. CV. Rajawali, Jakarta.

Smith, Jr.C.W \& Watts., R L., 1992 "The Invesment Opportunity Set and Corporate Financing, Dividend, and Compensation policies," The Journal of Financial Economics, December, pp 263-292.

Susantih, Heny dan Yulia Saftiana. 2009. Perbandingan Indikator Kinerja Keuangan Pemerintah Propinsi Se-Sumatera Bagian Selatan. Palembang: Simposium Nasional Akuntansi ke-12. 
Jurnal Progres Ekonomi Pembangunan (JPEP)

Volume 4, Nomor 2 , Tahun 2019

Page: $1-19$

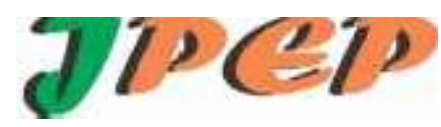

http://ojs.uho.ac.id/index.php/JPEP

e-ISSN: 2052-5171

Uma Sekaran, 2006, Metodologi Penelitian untuk Bisnis, Edisi 4, Buku 1, Jakarta: Salemba Empat.

Undang-Undang Dasar 1945

Undang-Undang Pemerintahan Daerah No. 1 tahun 1957.

Undang-Undang no. 5 tahun 1974.

Undang-Undang (UU) No. 32 Tahun 2004.

Undang-Undang (UU) No. 33 Tahun 2004.

Undang-Undang (UU) No. 33 pasal 66 /2004.

Undang-undang No.13 Pasal 36 Tahun 2006.

Undang-undang Pemerintahan Daerah No. 9 Tahun 2015.

V, Sebastiana., and Cahyo, Herman. 2016. Analysis of Economic Performance as The Independence Indicators of Government in East Java Province. Review of Integrative Business and Economics Research, 5(2), pp: 289-297.

Wulandari, Anita. (2001). Kemampuan Keuangan Daerah di Kota Jambi Dalam Melaksanakan Otonomi Daerah. Jurnal Kebijakan dan Administrasi Publik, Kemampuan Keuangan Daerah (Vol.5, No.2).

Yosephen, Mentari Sijabat, Chirul Saleh, Abdul Wachid. 2012. Analisis Kinerja Keuangan Serta Kemampuan Keuangan Pemerintah Daerah Dalam Pelaksanaan Otonomi Daerah(Studi pada Dinas Pendapatan Daerah dan Badan Pengelola Keuangan dan Aset Daerah Kota Malang Tahun Anggaran 2008-2012). Jurnal Administrasi Publik (JAP), Vol.2, No.2, Hal.236-242

Yuliati. 2001. Analisis Kemampuan Keuangan Daerah dalam Menghadapi Otonomi Daerah, Manajemen Keuangan Daerah. Yogyakarta: UPP YKPN.

Yuwono, Sonny dkk. 2008. Memahami APBD dan Permasalahannya (Panduan Pengelolaan Keuangan Daerah). Malang: Bayumedia Publishing. 